UDK: 339.97

Originalni naučni rad
POSLOVNA EKONOMIJA BUSINESS ECONOMICS

Godina XIII

Broj 1

Str $15-37$

doi: $10.5937 /$ poseko15-22040

Prof. dr Miroslava Filipović ${ }^{1}$

Univerzitet Edukons, Fakultet poslovne ekonomije, Sremska Kamenica Novi Sad

dr Milan Mihajlović ${ }^{2}$

Univerzitet Edukons, Fakultet poslovne ekonomije, Sremska Kamenica Novi Sad

Prof. dr Samed Karović ${ }^{3}$

Univerzitet Edukons, Fakultet za studije bezbednosti, Sremska Kamenica Novi Sad

\title{
POWER FOR GROWTH: G20 ECONOMIC POLICY AND INVESTMENTS
}

\begin{abstract}
The Group of Twenty (G20) has taken a premier role in devising a multistructural set of rules and recommendations for a new global economic regime. The paper identifies the G20 agenda development, detects major principles and norms for the issue area of investment, and concludes with an examination of some of the $\mathrm{G} 20$ results. The paper concludes that the G20 regime may prove effective if the commitments are upheld, more international actors involved, and a more balanced approach taken in devising such a regime.
\end{abstract}

Key words: global governance, G20, economic growth, regime.

\footnotetext{
${ }^{1}$ miroslavafilipovic@yahoo.com

2 mihamilan@gmail.com

${ }^{3}$ karovic.samed@gmail.com
} 


\section{INTRODUCTION}

For a long period, numerous research analyses have been pointing out that new, globalised world requires new arrangements for managing/governing its numerous interactive and interdependent paths. However, one had to wait for the latest global economic crisis for the major actors to take a more active approach towards devising a new world economic regime, or at least to join efforts to make the latest attempt, in a series of the US-led attempts (Desai, 2013), such as, for example the infamous Washington consensus of the late 1980 s, or the changes in international economic policy proposed and advocated by the Trump administration. The crisis of 2008 has not only triggered a disastrous economic 'tsunami' but has also emphasized growing interlinkages and widening economic discrepancies. In the words of Farer and Sisk (4)," ...too often, increments in global governance are the afterthought of disaster". "Everything is globalized - that is, everything except politics. The policy, authority, and resources necessary for tackling such problems remain vested in individual states rather than collectively in universal institutions. The classic collective action problem is how to organize common solutions to common problems and spread costs fairly" (Weiss and Thomas 2014: 213).

Since 2008, a plethora of ideas, proposals and plans have been put on the table, with only a partial success in their implementation. Although these ideas and proposals were sometimes quite different in nature and expected consequences, two basic dilemmas/challenges for all the involved actors remain: how to prioritize economic goals and devise norms for the global, interdependent economy (with a proper governance structure to oversee their implementation), and how to devise a system to have such agreed norms implemented in practice. At the beginning of the crisis, most of the actors were only interested in controlling financial damage and introducing new financial regulation. However, as the crisis was widening in its reach and depth, other questions arose: who will actually devise new rules, how would these supranational rules be implemented within national boundaries of hard law, who would monitor the implementation, what would happen to the autonomy of 'national policies', how to include other non-state actors and stakeholders, what would happen to actors/states/markets left outside global negotiations, how to deal with intensive issue linkages from various domains of economics, finance, development, energy, social inclusion, ecology and food security, etc.

Some of the challenges outlined above set the scene at which international community has started a political process aimed at designing new, global economic rules for this interconnected world economy. The Group of 20 (G20) has positioned itself in the centre, aiming at the creating a global economic policy forum, modelling grounds for more coordinated national economic policies and maybe building a basis for a world economic policy in 
a distant future. What we have also witnessed since 2008 is that, for the very first time, leading industrialized countries have invited emerging powers and other developing countries to join in managing global economic affairs (Schirm 2011).

The paper's main hypothesis is that a new economic world order or supranational regime is being created by the G20, and that its implementation could be successful if partial regimes for particular issues are developed. This will be tested in the area of investment for growth.

\section{GLOBAL GOVERNANCE AND REGIMES}

The evolution of responses to the 2008 crisis has proved to be a fertile ground for the implementation of global governance concepts and regime theories, although both theoretical frameworks had been introduced before that. It is said that the global governance concept came as a successor to 'world order theories', overcoming the latter's inability to grasp raising complexity of relations (not only top-down) and multitude of actors (Weiss and Thomas). "Three broad developments underpinned the appearance of the notion of global governance: the character of global problems, the nature of actors, and the perceived limitations of international measures to govern the planet." (Weiss and Thomas 2014: 209)

Since the crisis outburst, governments around the world have been implementing numerous and different measures in attempts to control the damage and revive economies, including banks' nationalization, bank capital augmentation, creation of safety nets, introduction of more restrictive financial regulation, fiscal consolidation, monetary tightening then loosening, etc. Three phases of the global/national economic policy could be identified: in the period 2008-2009, there was a widespread easing of both fiscal and monetary policies (to stimulate demand), while, at the end of 2008 the US started to act as a particular 'intentional lender of last resort' (Helleiner 2016) through FED swap line programme until February 2010; from 2010 to 2014, most governments (supported by the IMF and the G20) embarked on the fiscal consolidation and quantitative monetary-policy easing (to promote lending and liquidity); finally, in 2014, fiscal policy became more neutral while monetary policy of most countries expanded. Despite all this, economies did not respond as expected. Hence, most of governments realized that the crisis would continue for several more years unless certain structural changes in the global economic/financial order were implemented. Since 2013, measures have started to include other/wider economic and social goals as well, such as sustainable economic growth and employment, further tightening of coordinated financial regulation, trade, investments, green economy, inclusion, energy, etc. This supports 
arguments of numerous researchers and practitioners (though mainly outside the Anglo-Saxon domain) that the current phase of capitalist development and the related distribution of power needs substantial supranational support if the system is to survive.

Radhika Desai (2013) argues that what we are witnessing today is actually the most recent effort orchestrated by the industrialized countries (and led by the US) to create conditions somewhat similar but not the same as hegemonic-stability ones. As the global economy and its various subsystems present some of the major areas of concern today, and as there are general calls for new/updated regulatory arrangements to be created (Sorensen 2006: 7-9), the concept of global governance has to be introduced.

Most of the literature on global governance emphasizes its several key components: supranational arrangements, sets of rules and norms, actors' expectations, different layers and actors in the process, and necessary display of a certain level of representativeness, inclusiveness, efficiency, adaptability and fairness (Biersteker, 2011).

Throughout the global governance literature, Rosenau's interpretation has been widely used: “... global governance is conceived to include systems of rule at all levels of human activity - from the family to international organizations - in which the pursuit of goals through the exercise of control has transnational repercussions" (Rosenau 1995: 13). Dingwerth and Pattberg (2006: 186) distinguish “... global governance as a set of observable phenomena, and global governance as a political program", as two complementary ways of approaching and understanding it. Such a description has proved particularly useful in analysing the activities of the G20. Karns and Mingst (2009) based their interpretation of global governance on a description provided by the Commission on Global Governance in 1995: "Governance is the sum of the many ways individuals and institutions, public and private, manage their common affairs. It is a continuing process through which conflicting or diverse interests may be accommodated and co-operative action taken. It includes formal institutions and regimes empowered to enforce compliance, as well as informal arrangements that people and institutions either have agreed to or perceive to be in their interest."(Karns and Mingst, 2009: 3-4). It has to be emphasized that, in addition to hard law (rules), international organizations and extemporized arrangements, Karns and Mingst include specific norms of soft law in the components of global governance, i.e. in the process of new 'ordering' (Josifidis and Losonc 2014: 598), as a way to surmount the obstacles built by hard-law boundaries. . As Josifidis and Losonc argue, "Order ... is constructed; it represents a societal construct, and is a result of intersecting processes of conflict and cooperation in interdiscursive relations of society." (Josifidis and Losonc 2014: 598). 
Kratochwil (2013) gives another dimension to regulation, especially from the international legal aspect: "...the real problems of praxis lay in the dilemmas created by colliding duties or in bringing a concrete problem under different descriptions which require (justify) different norms." (Kratochwil 2013 , 3). Instead of forcing the application of existing norms (derived from universal principles of market economy and economic regulation), Kratochwil concludes that it would be more appropriate to create new agreements on certain shared practices. These views had previously been extensively developed by regime theories of international relations, exemplified by Krasner (2007) who defines regimes “... as sets of implicit or explicit principles, norms, rules, and decision-making procedures around which actors' expectations converge in the given area of international relations" (Krasner 2007: 3). The rise and development of the regime theories and practice can also be viewed as responses to the need to understand supranational issues and their regulation in the absence of a single pole/power/regulatory authority, i.e. in a multipolar reality of the today's unevenly developed world (Desai, 2013). As Moltke (2000: 37) has put it "...it is now becoming increasingly common to speak of international "regimes," groupings of actors, whether states, public or private organizations, or individuals, acting at the international level to address jointly defined problems or to achieve jointly defined goals based on mutually agreed rules of behaviour. "

The regime theories are particularly useful when politics focuses specific issues or issue areas, for example, current international debates about crossborder financial regulation or a complex issue area of the current economic crisis as a whole (its roots, consequences and modes of management to revive global economic growth, issues interlinkages). Although such complex regimes face a multitude of challenges and operational problems, a number of positive effects may be identified, as argued by Keohane and Victor, (2011): an advancement of supranational regulation of a complex issue area, may come from the progress reached on specific issues therein, which will in turn make more stable (wider) grounds for a future, comprehensive regime regarding the whole issue area to emerge.

The analysis that follows takes these criteria as the basis for assessing the role of G20 in creating global regulatory arrangements, with a special emphasis on investment for growth as a specific issue.

\section{G20 AND GLOBAL ECONOMIC AGENDA}

The embryo of today's G20 can be traced back to 1999 when, as a response to the financial crises, finance ministers of the major industrialized (first of all, Canada and the US) but also some emerging market countries, 
formed a new group in order to foster the cooperation on cross-border financial issues and regulation. Today, the G20 positions itself as a major forum for pooling efforts in developing new global economic policy. Several reasons may have contributed to the G20's rising profile: the crisis of 2008 has created favourable conditions for the growth of international cooperation on global economic and financial issues; despite many criticism the G20, it is representative as it gathers leaders of the economies that make a major part of the global economy; the G20 actively involves the members' leaders, thus a growth in its legitimacy; the G20 has proved to be very adaptable (in terms of its agenda development and external relations management), and a certain level of its efficiency can be recorded as it has managed to deliver some results upon numerous commitments made. It has been accepted that the G20 has been "been effective in moving together to stabilize financial markets, coordinate regulatory reform and launch a global economic stimulus" (Heinbecker 2011: 2).

However, some authors think that the shock of 2008 was so great that "...exposed the new, equalizing vulnerabilities of all countries, the failure of other international institutions to cope, the rising capabilities and increasing openness of the non-G7 members, the domestic political cohesion that participants brought, and their rational attachment to a compact G20 club at the hub of a global governance network in an interconnected world." (Kirton 2014: 45) Others (Schirm) emphasize its uniqueness also from the agenda aspect (wider than the ones of specialized international organizations) and impact aspect (gathering the members' leaders that may be more conducive for reaching common understanding and for yielding results at national level)

Global political deliberations within the group have reached their peaks on the leaders' summits: the G20 summit meetings in Washington (2008), London and Pittsburgh (2009), Toronto and Seoul (2010), Cannes (2011), Los Cabos (2012), Saint Petersburg (2013), Brisbane (2014), Antalya (2015), Hangshou (2016) and Hamburg (2017).

During these years, the G20 agenda has changed its priorities and the values ranking, under various paths of influence and on the basis of different individual values and agendas of the actors involved. These changes have not only involved changing the agenda items (e.g., from private actors' risk taking to sovereign financing) and rankings of agenda items (e.g., from the prominence of financial regulation in 2008 to that of employment in 2011), but also changes to the agenda's comprehensiveness (from financial regulation in 2008 to monetary and fiscal coordination in 2011 and employment in 2012 and 2013 , and further to sustainable global growth in 2014, investments and social issues in 2015), its geographic focus (from the US in 2008 to Europe and the East in 2011, to Latin America in 2012 and Europe again in 2013, to Australia in 2014, and back to Europe in 2015) and modes of the Group's functioning 
(from the top leaders to specific ministerial meetings, newly formed tracks of work and the group's bodies). Despite various tracks of the agenda development and shifting, it is possible to make an outline of a body of global principles and rules that have started to emerge under the auspices of the G20.

The first three summits (Washington, London and Pittsburgh 2008/2009) emphasized the need to establish rules of cooperation and coordination in financial regulation among the members, both internationally and at national level of regulation. London summit was very important as it produced a basic set of norms for further actions, thus actually building foundation for a new international economic regime to emerge. One can identify four different types (or levels) of norms proposed by the G20: global standards (most binding, applicable to all countries: related to accounting standards and principles), internationally-agreed norms (subject to separate agreements: financial system regulation), best practice (desirable, recommended: activities of credit rating agencies) and a consistent approach (most flexible: basic principles of national financial regulation, for example, coverage and boundaries).

In 2010, the summits in Toronto and Seoul brought the first important agenda widening - inclusion of macroeconomic policy guidance. Two years after the crisis beginning it became evident that focusing only on the financial issues could not boost the world economy revival. The Seoul summit resulted in the second wave of the agenda widening as it focused more on development issues, economic revival, employment and social protection. Also, another significant development of the summit was that the members pledged to develop a common view of global economic problems. For our analysis, this is a point where probably a new set of principles or underlying values have started to appear, thus making the underlying structure of a new global economic regime. Those principles would, at the same time, define the regime basic characteristics (Krasner 2007). It has to be emphasized that the previous summits focused on a need to develop particular rules/practical standards in the issue area of financial regulation, in order to handle the crisis. This prominent shift accentuated a central position of macroeconomic policy, especially fiscal policy and debt reduction, as well as market-based currency policy. The Seoul Summit was assessed as successful due to its 'globally predominant, internally equalizing capabilities among members of the group' (Kirton 2010, 7). This is particularly true if advances in national financial regulation and safety nets are reviewed, but much less true for reforms of international financial organizations, supporting the arguments of Keohane and Victor (2011) regarding the possibility of different pieces of progress for different segments of a regime.

The Cannes summit in 2011 allowed for further agenda broadening and brought certain changes as to the way the group functioned: a G20 Task Force on Employment has been set up and many multilateral organizations (e.g., 
IMF, ILO and World Bank, IOSCO, OECD) were invited to join the group's activities. This proves a relatively high level of the group's adaptability: although its members produce $90 \%$ of the world GDP and despite its strive to become a centre of global economic governance, numerous global economic issues may be beyond reach of such an informal, minilateral group (Grevi 2010: 3 ).

The 2012 Summit in Los Cabos resulted in further agenda development, with five priority areas: economic stabilization and reforms, financial system strengthening and financial inclusion, remodelling the international financial architecture, improving food security and reducing the volatility of commodity prices, and promotion of sustainable development, green growth and sound environmental policies. The 2013 G20 Summit in Saint Petersburg supported sustainable, inclusive and balanced growth and job creation at the worldwide level, through quality jobs and investment (dealing with structural unemployment, vulnerable groups, food protection, infrastructure, human capital), confidence and transparency (IMF reform, government borrowing and fighting corruption), as well as through effective regulation. Apart from that, the leaders stressed a need to improve mutual confidence, enhance the principle of fairness and create an overall set of rules: "We understand that sound and sustainable economic growth will be firmly based on increased and predictable investments, trust and transparency, as well as on effective regulation as part of the market policy and practice. As Leaders of the world's largest economies, we share responsibility for reinforcing the open and rulesbased global economic system." 4

The 2014 Brisbane Summit agenda highlighted several critical issue areas, such as investment in infrastructure, reduction of trade barriers (the area which has been not much complied with since 2008), promoting competition, employment and participation, modernizing the international tax system (the area which has been the most contentious one since 2008), increasing the energy market resilience, fighting corruption, etc. In 2015, the leaders met in Antalya (Turkey) and the final communiqué reiterated certain commitments (robust and inclusive growth, and support to employment rise), brought to the forefront some particular issues, such as investment growth, economic inclusiveness and the members' delivery upon commitments, but also expanded the desired reach of the group by calling for a dialogue with low income developing countries.

"To provide a strong impetus to boost investment, particularly through private sector participation, we have developed ambitious country-specific investment strategies, which bring together concrete policies and actions to improve the investment ecosystem, foster efficient and quality infrastructure,

\footnotetext{
${ }^{4}$ From: http://www.g20.utoronto.ca/2013/2013-0906-declaration.html
} 
including by the public sector, support small and medium sized enterprises (SMEs), and enhance knowledge sharing. Analysis by the OECD indicates that these strategies would contribute to lifting the aggregate G20 investment to GDP ratio, by an estimated 1 percentage point by $2018 " .5$

If one recognizes international regimes as a possible form of global governance (Krasner, 2006) and applies that model to the G20 commitments and proposed measures, it is possible to outline some of the cornerstones (basic principles and norms) of a global economic policy defined by the G20. They include several distinct but overlapping transnational issue areas. Markets should remain open and liberalized (including the norms of diminishing state intervention, structural reforms of labour market and tax systems, etc.), as well as international trade (with the norms to eliminate protectionist barriers). States should carry out a sound macroeconomic policy (through the norms of fiscal deficit reduction, debt stabilization, and refraining from currency manipulation). International liquidity is of the utmost importance for the global economic revival (hence, international financial institutions should be modernized; liquidity surveillance should be reinforced, etc.). Financial regulation should be improved and coordinated across boundaries to allow for the financial markets' integrity and transparency (with the norms of global accounting standards, higher capital base for banks, integrated stress testing mechanisms, prevention of illicit financial flows, development of global safety nets, etc.). Growth policies should be coordinated while targeting economic rebalancing on the world scale (budget expenditures and revenues to support productivity, inclusiveness and growth, avoidance of negative spill-overs, measures to support demand, investments, and structural reforms, etc.).

Nevertheless, the comprehensiveness of the guidelines given and regulation proposed varies between the segments of a new global regime, supporting the argument of Keohane and Victor (2011) that regulatory advancements can be made in distinct parts of a transnational issue area even in the absence of a single, unified regime. So, norms were designed and commitments made, but what is left as a critical component in devising a global economic policy is their implementation at the national level.

\section{G20 AND INVESTMENTS FOR GROWTH}

There is no need to elaborate here on a multifaceted link between investments and economic growth but what deserves attention is the longevity and comprehensiveness of international political deliberations to regulate such flows. Cross-border investments have for a long time been an area where

\footnotetext{
${ }^{5}$ http://www.g20.utoronto.ca/2015/151116-communique.html
} 
bilateral, regional and multilateral political efforts gave rise to various regulatory schemes through thousands of investment treaties ${ }^{6}$. "One may argue that international investment treaties as a group represent a convergence of expectations by states as to how host governments will behave toward investments from other regime members. The norms and rules embodied in investment treaties are intended to constrain and regularize such behaviour in order to fulfil those expectations."'(Salacuse 2010: 431) Despite the treaties obvious positive results in enhancing cross border capital flows and regulating the associated risks, global economic changes call for their re-examination (Gordon and Pohl). Such changes include structural transformation regarding capital origin (certain capital importing countries have become net creditors, and vice versa), ex-post legal and political re-evaluation of such treaties, a significant rise in investment disputes, a need to focus sustainable development and inclusive growth, etc. ${ }^{7}$ As such treaties primarily belong to the area of international investment law, this is somewhat outside of the focus of this paper. Nevertheless, a sheer existence of network of international investment treaties (although pieces of this network are not structurally linked between themselves) can contribute to our understanding of how international politics can devise global economic governance/regimes around two sets of regime norms: agreed/standard investment treatment and defined enforcement mechanism. In addition, two principles of the international investment regime - rise of investments leads to economic development, adequate investment climate attracts more investments - (Salacuse 2010: 451) can form a solid ground for analysis of the G20 efforts to create a global policy regime wherein investments can induce further economic growth.

\footnotetext{
${ }^{6}$ According to UNCTAD data, there are 2278 bilateral and 285 international investment agreements in force. Details available from http://investmentpolicyhub.unctad.org/IIA (accessed 08. 04. 2016)

${ }^{7}$ See: UNCTAD, Issue Note 1, March 2016, from http://unctad.org/en/PublicationsLibrary/webdiaepcb2016d1_en.pdf (accessed 09. 04. 2016)
} 
Graph 1: G20 Commitments by major issue areas (2008-2015)

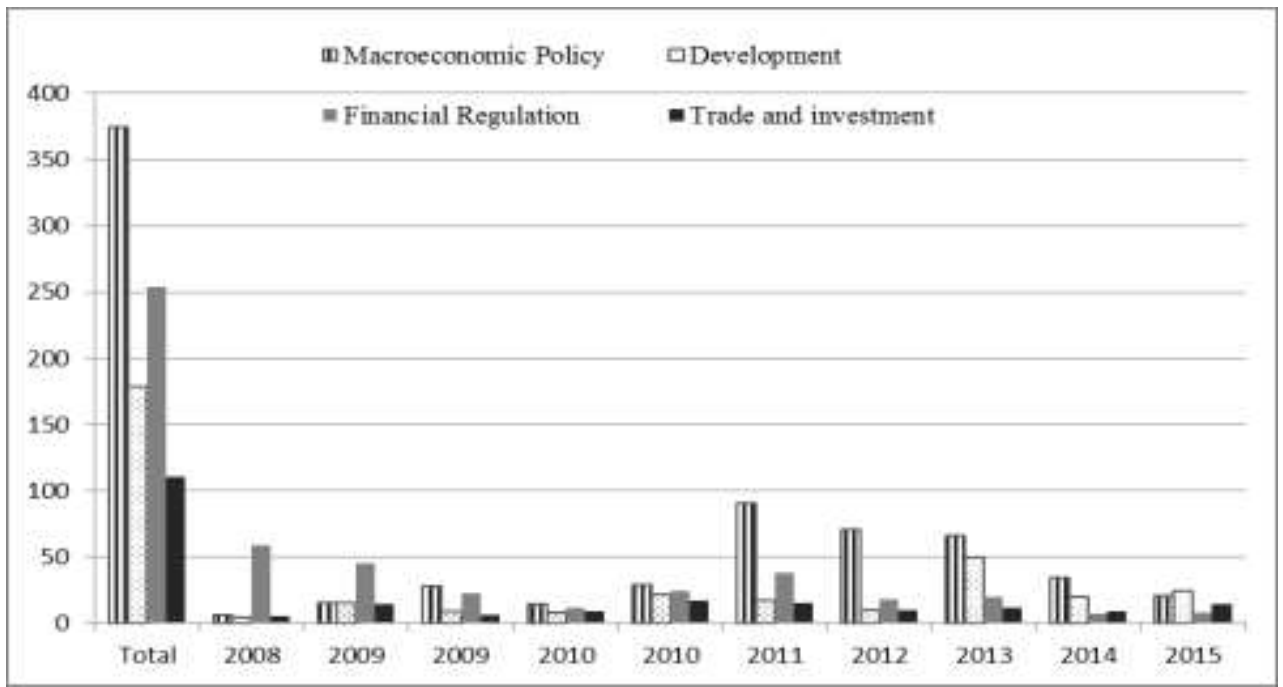

Source: http://www.g20.utoronto.ca/compliance/commitments.html

Bearing in mind that the issue of investments has been included in both development and trade/investment issue areas, the graph above shows how the attention of the G20 leaders has shifted since the first summit in 2008. As the recovery was gaining momentum, the agenda and the commitments were targeting much less macroeconomic policy and financial regulation and more some of the development and trade/investment issues.

The G20 has not dealt openly with international investment treaties, but has deliberated about investments within macroeconomic, financial regulation, development, trade and social inclusion sub-areas. Although the issue of investment growth has been included in the G20 agenda for a number of years, it was not until the Antalya summit that the issue ranking rose sharply. A reason for that might be that the group's numerous action plans from the previous summits had not delivered the planned and desired global economic growth, despite the acknowledgements that investments and trade are engines of growth. If, in the words of regime theorists, regimes are based on a belief by their members that cooperation in a specific issue area will lead to a desired outcome (regime principles), one can understand that a pure statement of the G20 leaders that investments are keys to growth had not been backed by an elaborated set of norms and rules, or guidance for members' investment policy.

The evolution of the G20 approach towards building a new set of global rules (or at least guidelines) for investment could be illustrated by reviewing the commitments taken at different group's summits. Some of the earlier commitments taken by the G20 leaders in the area of investments include the following 'G20 members should': 
- minimise any negative impact on trade and investment of the domestic policy actions including fiscal policy and action in support of the financial sector (2009);

- refrain from financial protectionism, i.e. measures that constrain worldwide capital flows, especially to developing countries (2009 and all subsequent summits);

- strengthen domestic sources of growth (external-surplus countries) by increasing investment, reducing financial markets imbalances, etc. (2009, Pittsburgh);

- increase infrastructure spending (2010 and all subsequent summits);

- support development financing, from public and private sources, through concessional and multilateral lending facilities, including technical support (2010 and 2012);

- reform tax system for widening investment incentives (Seoul, 2010);

- redirect surplus savings towards investments in developing countries, particularly infrastructure development (2011 and all subsequent summits);

- work towards reforming national investment environments in order to attract long-term, private capital, and improve the efficiency of public investment (St. Petersburg, 2013);

- The US committed to implement measures to support public investments, Germany, Japan and Indonesia committed to boost spending and investments, while Germany and Italy committed to tax reform aimed at increasing employment (2011, Cannes);

- the EU members of the G20 committed to more efficient use of the European Investment Bank, pilot project bonds, and structural and cohesion funds, for more targeted investment (Los Cabos 2012). ${ }^{8}$

At the 2014 Summit in Brisbane, the G20 leaders again acknowledged that global investment and infrastructure are critical for supporting economic growth, employment rise and productivity improvement. Therefore, public investment should be strengthened and national investment climate improved, while constantly working towards attracting more private capital for investment.

The 2015 G20 Leaders' Communiqué identifies several paths of improvement if investments are to become true engines of growth. Maybe most importantly, the group has called its members to continue improving investment climate and framework in their economies by supporting wider institutional investors' involvement (pension funds, insurers, mutual funds and sovereign wealth funds) in the financial markets, developing alternative capital

${ }^{8}$ For details see: http://www.g20.utoronto.ca/compliance/commitments.html 
market instruments, creating conditions for rise of long-term financing, and improving infrastructure project preparation. This call for investment climate/framework improvement can be, in the regime theory tradition, regarded as an emerging norm, not fully developed (as it misses the component of regime members' rights and obligations) but specific enough to give raise to potential regime rules.

After the 2016 G20 Summit in China, the communiqué reiterated the need to work upon building open and transparent global environment for investment which would, in turn, result in further economic growth. The leaders agreed on principles that should guide investment policymaking in the G20 area and also worldwide, as cross-border investment policy coherence is being accentuated. ${ }^{9}$

The 2017 G20 summit declaration, despite rising economic nationalism and protectionism thinking in the US and elsewhere, reiterated a necessity for deeper cooperation in trade and investments as their growth seemed insufficient to strengthen economic resilience worldwide. "International investment can play an important role in promoting inclusive economic growth, job creation and sustainable development, and requires an open, transparent and conducive global policy environment" (G20 Leaders' Declaration, 4).

One of the latest reports on G20 members' investment strategies (G20/OECD report on investment strategies) emphasizes a systemic approach to improving investment climate and framework that relies on several interrelated elements: creation and maintenance of credible, sustainable and transparent macroeconomic policy; development of appropriate long-term investment strategies (to be implemented at different governmental levels and in various economic sectors); ensuring efficient cooperation across levels of government; identification and involvement of relevant stakeholders (both public and private) in the strategies development and implementation, and proper placement of investment strategies within the whole of economic policy, with a special emphasis on their links to national growth strategies, financial stability and prudential policy, fiscal policy, competition and SME policy, labour reforms, education policy, etc.

Further analysis point out that a certain amount of regime rules (desired/prescribed patterns of action) is beginning to emerge. Public-privatepartnership has been prioritized as the most desirable and effective model of boosting investments, with small and medium size enterprises (SMEs) being brought to the forefront. For that reason, new financial structures (asset-based financing, movable collateral options, improvements in credit reporting

\footnotetext{
${ }^{9}$ The list of principles can be found at http://www.oecd.org/daf/inv/investment-policy/G20Guiding-Principles-for-Global-Investment-Policymaking.pdf
} 
systems, lending by non-banks to SMEs, transparent securitization, longerterm funds, reorganization-oriented insolvency regimes) should be devised to enhance SMEs' access to funds. These goals have been further operationalized through sets of guidelines and best practices ${ }^{10}$ for public-private-partnership models. "The G20 should encourage G20 countries and non G20 countries to fully develop credit infrastructure for SMEs, improve SME financial capability through targeted learning and support interventions and enable competition through an enabling regulatory environment". ${ }^{11}$ As for the sector, investments in infrastructure have been again highlighted, and particular attention has been paid to raising efficiency of public investment in sustainable infrastructure projects in emerging markets and low-income countries, in order to achieve a three-sided goal: be responsive to global demographic changes, take into the account environmental safeguards and climate shifts, and contribute to decreasing levels of inequality. Funding of private sector has also been emphasized as one of the priorities, especially focusing on multilateral and national development banks' and foreign direct investments' roles in that respect. National regulators have to ensure non-discrimination and investors' protection, while governments should continue international investment dialogues, both multilaterally and bilaterally.

\section{BEYOND COMMITMENTS: RESULTS ACHIEVED}

Although the concept of global governance and regime theories might have proved useful in approaching the research problem, it is just not enough to describe the actors, process and settings, but one must strive to detect and analyse what outcome has been achieved through this form of 'governance', has the result been effective, and if not what kind of work/compromises/governance should be done to have further results meeting the needs of a growingly interdependent world economy (Weiss and Thomas 2014: 211). The previous part of the paper proposed a view of the proposed investment regime, while the rest of the analysis seeks answers to the second question - has this result (a proposed global regime for investments) been implemented and was it effective.

\footnotetext{
${ }^{10}$ For details see: Overview of World Bank Group Infrastructure Deliverables for the G20 Investment and Infrastructure Working Group, 2015, Washington, D.C: World Bank Group ${ }^{11}$ From "G20 Action Plan on SME Financing - Joint Action Plan of G20 GPFI SME Finance Sub-Group and IIWG", Antalya, Turkey, 2015, available from http://www.g20.utoronto.ca/2015/151116-communique.html\#annex
} 
Graph 2: GDP growth, annual \% (2007-2016)

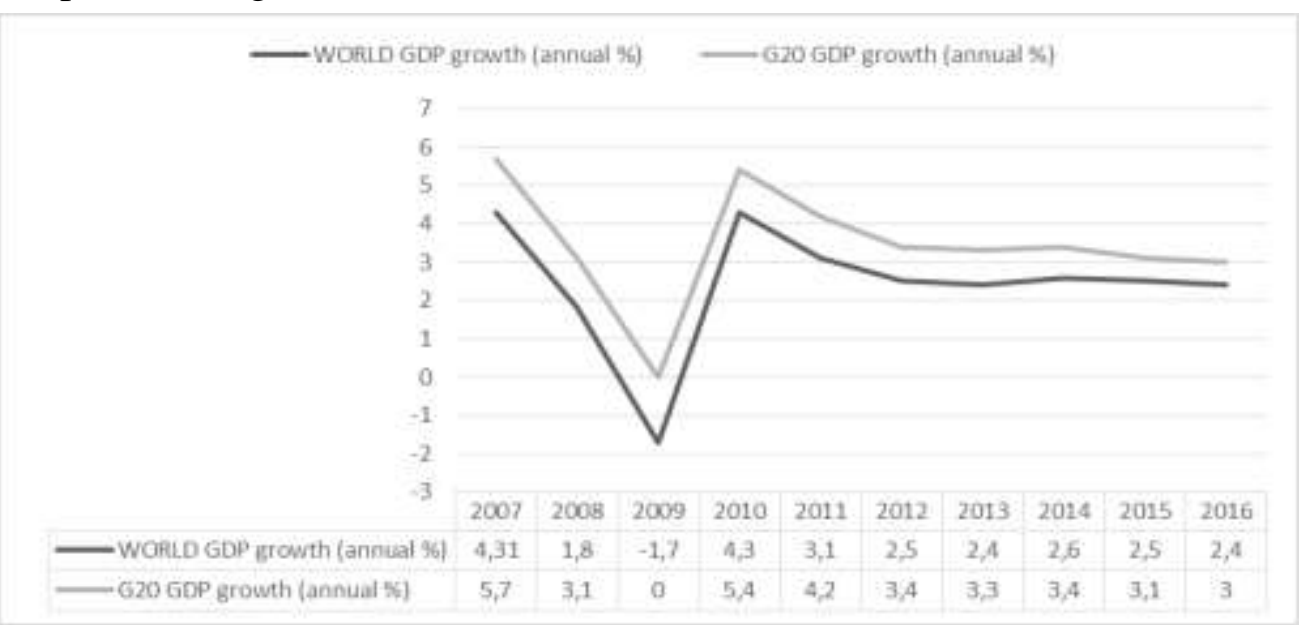

Source: http://data.worldbank.org/indicator/NY.GDP.MKTP.KD.ZG

As for the overall result of the G20 actions, Graph 2 shows that both immediate and longer-term effects of the crisis were felt to a slightly lesser extent in the G20 (though this has also to be attributed to the stronger economic health). However, the downward and upward trends for the world GDP and the G20 seem parallel in the period 2007-2016, although the gap has been narrowing since 2015.

Among various macroeconomic conditions for an upward trend in investments, economic predictability and tightness/looseness of monetary policy rank very high. Data show very different levels of inflation among the G20 members, where the leading industrialized countries on average scored far better - especially in comparison with the some BRICS countries. After 2011, most of the G20 members pushed hard to control consumer prices, so, in 2015, China, Canada, Italy, the UK, the US and France inflation was ranging from 0.5 to $2 \%$.

${ }^{12}$ Data available from http://data.worldbank.org/indicator/FP.CPI.TOTL.ZG 


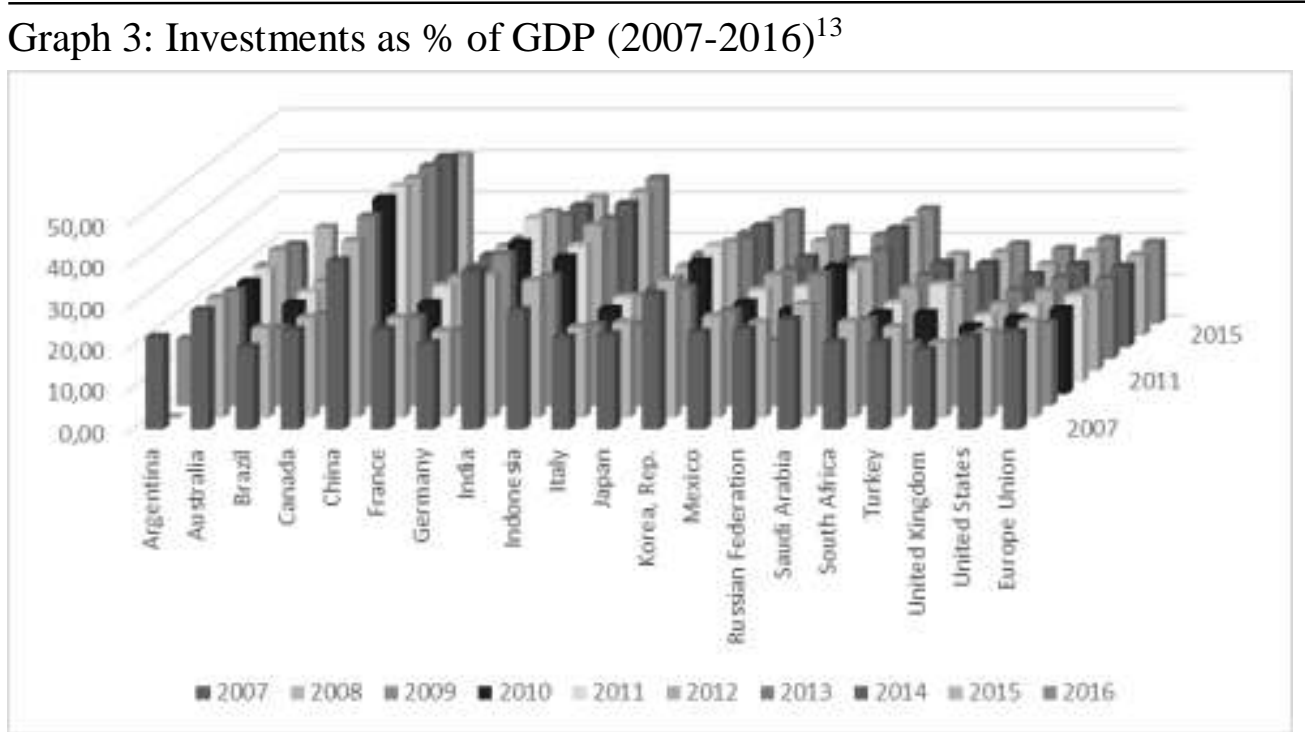

Source:http://www.economywatch.com/economic-statistics/economicindicators/Investment_Percentage_of_GDP/

As for the most direct indicator of the G20 members' commitment to increase investments -investments to GDP ratio (Graph 3) - it seems that most of the countries have recorded a decline, despite their declaratory commitment. Only China and Indonesia have increased the share of investments in the GDP, while in Brazil, Canada and Japan it remained virtually the same when 2007 and 2016 are compared. Most significantly, investments in the EU as a whole declined in the same period from $23.42 \%$ to $19.56 \%$. Just for comparison, investments in China in 2016 were $41.82 \%$ of the GDP.

Another important indicator for investments is the cost of long term capital. For the Euro area as a whole, long term interest rates have declined 3.5 times in the period 2008-2016, most notably in 2011/2012 and 2014/2015, to an average level of $0.93 \%$ annually. Germany has gone even further in dramatically reducing the interest rates almost from $3.98 \%$ to $0.09 \%$, second only to Japan (with negative rates of $-0.07 \%$ ), in 2016. Both the UK and the US have more than halved interest rates in the period. BRICS countries (except China) have kept their interest rates very high, ranging from $7 \%$ to over $8 \%$ annually ${ }^{14}$.

If we analyse the stability and inflows to the G20 members' budgets, as one of the critical precondition for growth in public infrastructure, the period 2008-2015 shows relatively constant rates ${ }^{15}$. Fiscal revenue as a percentage of

\footnotetext{
${ }^{13}$ Due to differing accounting frameworks, data for some countries include gross domestic investment and net foreign investment.

${ }^{14}$ Data available from http://www.principalglobalindicators.org/regular.aspx ?key=60942001

${ }^{15}$ Data available from http://www.principalglobalindicators.org/regular.aspx ?key=60942000
} 
GDP rose only in China from $19.34 \%$ (2008) to $23.57 \%$ (2015), although it still lags significantly behind some of the most developed countries (France $53.45 \%$, Japan $-50.8 \%$, Italy $-47.94 \%$, all for 2015 ). Fiscal revenue of the Euro-area, as a whole, was $46.41 \%$ of the GDP in 2015.

Together with capital costs, tax rates are certainly one of the most important factors for investment considerations. If we analyse total tax rates in the G20 members, as a percentage of commercial profits and excluding personal income taxes and VAT, it can be concluded that this indicator shows the largest diversity of fiscal environments, ranging from $68.4 \%$ (Brazil) and $68.2 \%$ (China) to $15.7 \%$ (Saudi Arabia). The majority of most developed countries in the group impose taxes in the range of 30-60\%. Despite strong commitments to alleviate business burdens, just a slight downward trend can be detected between 2007 and 2016. Only Canada significantly reduced the total tax from $44.3 \%$ (2007) to $21 \%$ (2016), while the taxes in the Euro area declined from $45.38 \%$ (2007) to $41.3 \%(2016)^{16}$.

Graph 4: Incentives to invest (2015-2016)

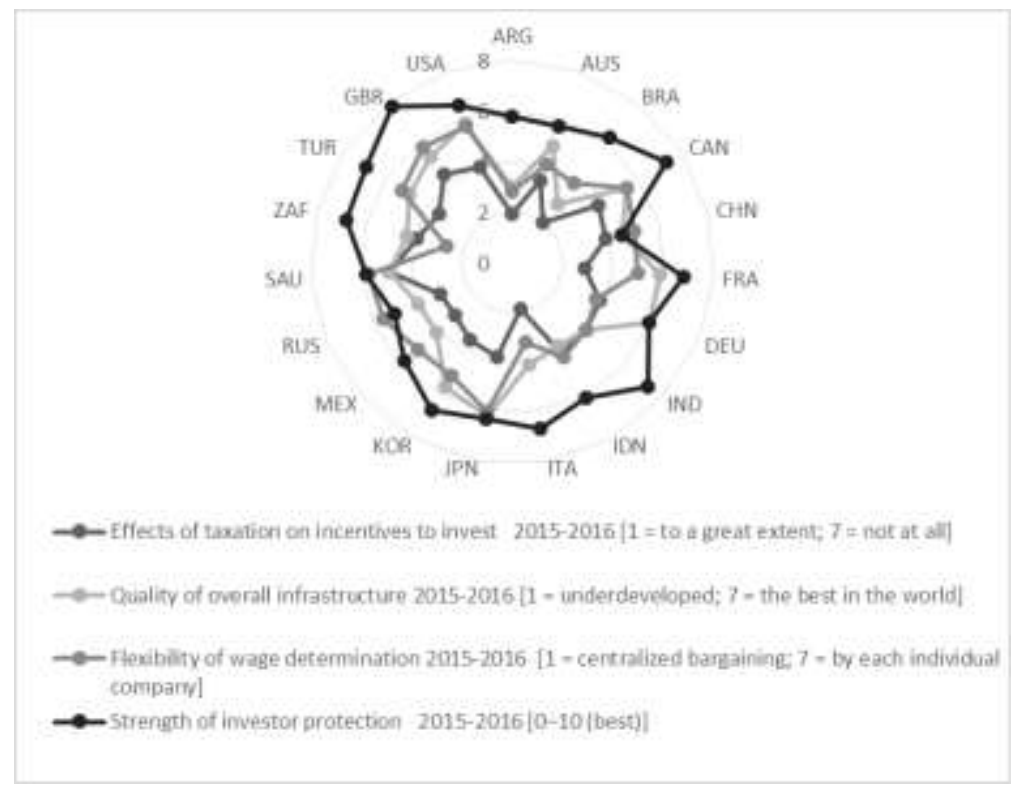

Source:http://reports.weforum.org/global-competitiveness-report-20152016/competitiveness-rankings/

Directly linked to the official level of taxation are perceived effects of taxation on incentives to invest (Graph 4), among other competitiveness indicators of the World Economic Forum. From that aspect, in 2015-2016, investors in Brazil, Argentina and Italy see the taxation as greatly reducing

\footnotetext{
${ }^{16}$ Data available from http://data.worldbank.org/indicator/IC.TAX.TOTL.CP.ZS
} 
incentives to invest, while those in Saudi Arabia, the UK, the US and Canada do not perceive taxation as a significant disincentive for investment. Another important aspect for increasing investment is quality of overall infrastructure, where the EU members of the G20, together with the US and Japan are ranked the highest. The group has delivered upon the third aspect of rising investment incentives - flexibility of wage determination (centralized vs. decentralized), where most of them, except Germany and Italy, recorded scores in the upper part of the scale (much more discretion at company's side). Almost all of the G20 members provide relatively strong investor protection, with the UK and Canada leading and China lagging in this respect.

The importance of growth of private capital resources for investments have been reiterated on several G20 summits, but in the period 2010 to 2016 most of the G20 members did not deliver on this commitment, as Graph 5 shows. If one analyses the level of domestic credit to private sector as a percentage of GDP, a decline or stagnation is evident in most countries except China (with a rise of $20 \%$, China reached a level of $156 \%$ of the GDP being lent to private sector in 2016). In the EU as a whole, this decline amounted to $18 \%$ and even more in the UK (30\% decline), while the US constantly lends approximately $200 \%$ of its GDP to private sector. It also has to be noted at the overall level of this lending varies greatly among the G20 members, due to different economic and political reasons: it ranks from 13\% in Argentina to $192 \%$ and $184 \%$ of GDP in the US and Japan respectively.

Graph 5: Domestic credit to private sector (\% of GDP)

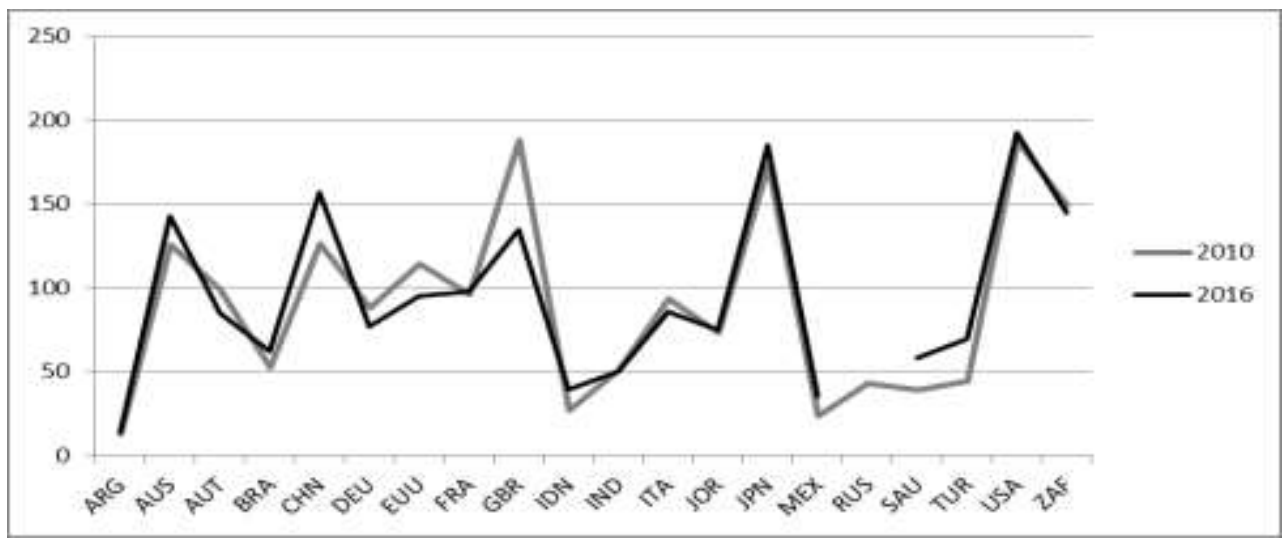

Source: http://data.worldbank.org/indicator/FS.AST.PRVT.GD.ZS

Note: a) taxes reduce the incentive to invest $[1=$ to a great extent; $7=$ not at all $]$; b) the general state of infrastructure [ $1=$ extremely underdeveloped among the worst in the world; 7 = extensive and efficient - among the best in the world]; c) how are wages generally set? [ $1=$ by a centralized bargaining process; 7 = by each individual company]; d) Investor Protection Index on a 0-10 (best) scale. 
As for the G20's commitments to provide wider support to SMEs and facilitate their market entry, one can conclude that the members delivered on these commitments, at least from the aspect of time needed to start a business. According to this parameter, in the period 2008-2016, time needed to start a business was reduced from 11-13 days to around 2-7 days in most developed of the G20 members, with BRICS countries lagging far behind ${ }^{17}$,

Indicator of newly registered business shows varying results, where the EU as a whole recorded a decline of new business (between 8 and 10\%, depending on the country) except in the UK where the new registrations soared by almost $60 \%$, in the period 2009 to $2012^{18}$.

Regarding the measures directly linked to investments, the results among G20 members are mixed: some have introduced measures for greater openness to foreign direct investments (Brazil and Mexico), while others have imposed further restrictive measures in this domain (e.g. Australia) or applied both liberalization and restriction measures (Canada and China). Some have eased international capital flows (Argentina, India, South Korea and China), while a number of new bilateral (Saudi Arabia, Japan, Turkey, Argentina) or international investment treaties (US, EU, Canada) have been concluded or extended (Seventeenth Report on G20 Investment Measures, 2017).

To summarize, the G20 members have differently followed the commitments they jointly made in the area of increasing investments for growth. Although the selected indicators might not give a detailed picture of the members' actions and achieved results, one can conclude that the G20 members have invested most of their efforts in creating a stable macroeconomic environment (inflation control and stable fiscal revenue), improving the quality of overall infrastructure, lowering long-term interest rates and keeping investor protection high. Some results were achieved in alleviating administrative burden for start-ups and flexibility of wage determination but they failed to deliver on tax-burden easing and improving domestic finance to private sector. Finally, they did not produce results upon the commitment to increase investments.

\section{CONCLUSION}

One of the rare beneficial consequences of the current crisis is that international community has gradually shifted its focus from providing assisting the distressed financial sector to tackling more fundamental aspects

\footnotetext{
${ }^{17}$ Source: http://data.worldbank.org/ indicator/IC.REG.DURS

${ }^{18}$ Data available from http://data.worldbank.org/indicator.
} 
of economic functioning world wide. Since 2008, political debates about the future of world economy have brought forward two basic dilemmas: first, if today's world economy needs more guidance, the question is how to devise norms for the global, interdependent economy (with a proper governance structure to oversee their implementation), and secondly, how to devise a system to have the agreed norms implemented in practice. The paper started with a hypothesis that a new economic world order is being created by the G20, and its success is based on creating and implementing regimes for particular issue-areas. For that reason, the paper first examined global governance concepts and regime theories. Upon that theoretical ground, the outcomes of the G20 activities in creating a world economic agenda have been analysed. As the crisis effects were losing the strength and the recovery gaining momentum, the G20 agenda and the commitments were targeting much less macroeconomic policy and financial regulation, and more some of the development and trade/investment issues.

Our conclusion is that several broad principles for a future world economic regime, as advised by/committed to by the G20, include, inter alia, open and liberalized markets, free trade, sound macroeconomic policy, proper surveillance and management of international liquidity, and financial regulation and growth policies coordinated across borders.

Since 2015, a specific issue of investment has moved upward on the G20's agenda, and more commitments were made regarding this issue. It has been followed by different actions, plans and recommendations, engaging other international actors as well. A number of sub-principles for this particular regime could be identified: creation and maintenance of credible, sustainable and transparent macroeconomic policy; development of appropriate long-term investment strategies; ensuring efficient cooperation across levels of government; identification and involvement of relevant public and private stakeholders, as well as improved integration of investment strategies within the whole of economic policy.

We could also detect a certain amount of regime rules. Public-privatepartnership is the most desirable and effective model of boosting investments, with a special emphasis on small and medium size enterprises. Second, new financial structures should be devised to enhance SMEs' access to funds. Third, investments in infrastructure are potent growth engines. Fourth, funding of private sector should be one of the priorities. Finally, investment climate needs to be continuously improved, and governments should actively continue international investment dialogues, both multilaterally and bilaterally.

Nevertheless, after the analysis of the results of some of the G20's commitment regarding investment for growth, our conclusion is that the assessment of the proposed regime efficiency is a perplexing task, for a number of reasons. First, one cannot deny that economic growth has revived and if we 
agree that the G20's economies are motors of the world economic growth, we still have to see their impact in the rest of the world economy. Second, the time span for analysing the effects of the proposed regime for investments is too short for any unequivocal conclusions to be made. Third, the G20 members have delivered differently in specific areas of the investment issue - they failed to deliver on tax burden easing, improving domestic finance to private sector, and most importantly, they did not increase investments. In other areas certain results have been achieved, such as focusing macroeconomic stability, improving the quality of overall infrastructure, lowering long-term interest rates and keeping investor protection high.

When the importance and relevance of the G20 is examined, one can detect extreme opinions on this question: from those who see the G20 as redundant (too large and diverse), those who see the G20 as inferior to the IMF and the G7, those who consider the group useful, but with declining effectiveness, and those who praise the G20 for making significant contribution in various issue-areas of the world economy and some contribution in other critical issue domains (such as social rights, global health, climate change, etc.). The G20 may have taken the lead in creating a global economic policy forum, setting certain grounds for more coordinated national economic policies and maybe for a world economic policy in a distant future. Nevertheless, the G20's activities in creating and implementing a new regime for the global economy may further improve if positive experience from supranational governance concepts and models in other global-issues area are taken into the account. The effectiveness of the group's proposal for the investment regime may also improve if links with other international organizations and actors (not necessarily only from the developed world, such as development banks, for example) are established. Finally, the effectiveness of such a new regime could also benefit from a more balanced approach towards national differences (level and structure of economic development, national economic goals, peculiarities of national legal systems, etc.) taken regarding not only the group's members, but also the rest of the international community.

\section{REZIME SNAGA ZA RAST: G20 EKONOMSKA POLITIKA I INVESTICIJE}

Grupa dvadeset najrazvijenijih zemalja (G20) zauzela je vodeću ulogu u osmišljavanju višestruko strukturiranog skupa pravila i preporuka za novu globalnu ekonomsku politiku. Rad identifikuje program razvoja G20, otkriva glavne principe i norme za oblast ulaganja i donosi zaključke ispitivanjem nekih od rezultata programa G20. U radu se zaključuje da se politika G20 može 
pokazati efikasnom ako se preuzmu obaveze, uključi više međunarodnih aktera i da se pri osmišljavanju takve politike koristi uravnoteženiji pristup.

Ključne reči: globalno upravljanje, G20, ekonomski rast, ekonomska politika

\section{REFERENCES}

1. Biersteker, Thomas. 2011. Global Governance, the Sustainability of International Institutions, and the Potential Role of University-based Research Institutes. Paper presented at the Eight Glion Colloqium on Global Sustainability, Glio, Switzerland.

2. Desai, Radhika. 2013. Geopolitical Economy - After US Hegemony, Globalization and Empire. Pluto Press, London.

3. Dingwerth, Klaus and Phillip Pattberg. 2006. Global Governance as a Perspective on World Politics. Global Governance 12, 185-203.

4. Farer, Tom and Timothy Sisk. 2010. Enhancing International Cooperation: Between History and Necessity. Global Governance 16 (2010), pp. 1-12.

5. G20 Leaders' Declaration - Shaping an interconnected world, 2017. Available from https://www.g20.org/Content/EN/_Anlagen/G20/G20leaders-declaration.pdf?_blob=publicationFile $\& v=11$

6. G20/OECD report on investment strategies. 2015. OECD.

7. Gordon, Kathryn and Joachim Pohl. 2015. "Investment Treaties over Time - Treaty Practice and Interpretation in a Changing World", OECD Working Papers on International Investment, 2015/02, OECD Publishing.

8. Grevi, Giovanni. 2010. The G20: Panacea or window-dressing? Policy Brief, ISSN 1989-2667, Madrid: FRIDE.

9. Heinbecker, Paul. 2011. The Future of the G20 and its Place in Global Governance. CIGI G20 Papers, No. 5, Centre for International Governance Innovation, Waterloo, Canada.

10. Helleiner, Eric. 2016. Legacies of the 2008 Crisis for Global Financial Governance. Global Summitry, Volume 2 (1), Oxford University Press.

11. Josifidis, Kosta and Alpar Losonc. 2014. Some Thoughts on Power: International Context. Panoeconomicus, 2014, 5, Special Issue, pp. 597615.

12. Karns, Margaret and Karen, A. Mingst. 2009. International Organizations: The Politics and Processes of Global Governance, 2nd edition, Boulder, CO: Lynne Reinner.

13. Keohane, Robert O. and David G. Victor. 2011. The Regime Complex for Climate Change. Perspectives on Politics, Volume 9 (1), pp. 7-23, DOI: http://dx.doi.org/10.1017/S1537592710004068 
14. Kirton, John, J. 2010. A Summit of Substantial Success: The Performance of the Seoul G20. Retrieved from http://www.g20.utoronto.ca/analysis/kirton-seoul-perf-101113.html

15. Kirton, John, J. 2014. The G20 System Still Works: Better Than Ever. Caribbean Journal of International Relations \& Diplomacy, Vol. 2, No. 3, September 2014: p.43-60.

16. Krasner, Steven, D. 2007. Structural Causes and Regime Consequences: Regimes as Intervening Variables. In B. A. Simmons, R. H. Steinberg (Eds.) International Law and International Relations, Cambridge, MA: Cambridge University Press.

17. Kratochwil, Friedrich. 2013. Politics, law and the sacred. Journal of International Relations and Development, 16, p. 1-24.

18. Moltke, Konrad, von. 2000. An International Investment Regime? Winnipeg, Canada: Issues of Sustainability. International Institute for Sustainable Development, available from https://www.iisd.org/pdf/investment.pdf

19. OECD Seventeenth Report on G20 Investment Measures. 2017. Available from

https://www.wto.org/english/news_e/news17_e/g20_oecd_unctad_report june17_e.pdf.

20. Rosenau, James, N. 1995. Governance in the Twenty-first Century. Global Governance 1(1), 13-43.

21. Salacuse, Jeswald, W. 2010. The Emerging Global Regime for Investment. Harvard International Law Journal, 51 (2).

22. Schirm, Stefan A. 2011. The G20, Emerging Powers, and Transatlantic Relations. Transatlantic Academy Paper Series, Washington, D.C: Transatlantic Academy

23. Sorensen, Georg. 2006. What Kind of World Order? The International System in the New Millennium. Cooperation and Conflict, 41: 343-363.

24. Weiss, Thomas G. 2014. Rethinking Global Governance? Complexity, Authority, Power, Change. International Studies Quarterly 58, 207-215.

Ovaj rad je primljen 23.05.2018., a na sastanku redakcije časopisa prihvaćen za štampu 19.06.2019. godine. 